\title{
Global radioactive deposition on the Yenisey-river catchment and its contribution to the summary contamination of the valley
}

\author{
E. Stukin, E. Kvasnikova and V. Golosov ${ }^{1}$ \\ Russian Academy of Sciences, Institute of Global Climate and Ecology, \\ Glebovskaya Str. 20-b, 107258 Moscow, Russia \\ ${ }^{1}$ Moscow State University, Department of Geography, Laboratory of Soil Erosion \\ and Fluvial Processes, Vorobiovy Gory, 119899 Moscow, Russia
}

\begin{abstract}
The results of the retrospective global radioactive contamination mapping of the Enisey-river catchment are presented. The maps of spatial ${ }^{137} \mathrm{Cs}$ distributions of 1964, 1974, 1986, 2000 are compiled using the geoinformation technologies in the Institute of Global Climate and Ecology. The territory of mapping is $2600000 \mathbf{~ k m}^{2}$. The mapping is done from the airborne-gamma-spectrum data obtained at the beginning of 1960, of 1970 and 1990 . In 2000 the global levels of ${ }^{137} \mathrm{Cs}$ are $0.4-3 \mathrm{kBq} / \mathrm{m}^{2}$. A small contribution of Chemobyl deposition can be registered on the maps built later $1986\left(0.02-0.15 \mathrm{kBq} / \mathrm{m}^{2}\right)$. The levels of $2.5-3 \mathrm{kBq} / \mathrm{m}^{2}$ in the region of Severo-Eniseyski and Teya localities can be estimated as the tail part of the eastern Chernobyl pattern. The present levels of 2.59-122 $\mathrm{kBq} / \mathrm{m}^{2}$ are observed on the Enissey valley at distances of $0.1700 \mathrm{~km}$ from Krasnoyarsk-26. The parameters of runoff and soil erosion are estimated using the cartographic information, provided by the Laboratory of River Processes and Soil Erosion of the Moscow State University. A part of ${ }^{137} \mathrm{Cs}$, accumulated in the Enisey-valley from early 1960 to 2000 with the transport of soil material from interfluve of all Enisey tributaries, will be estirnated using a balance model of soil erosion. The contribution of ${ }^{137} \mathrm{Cs}$ from the catchment to the valley is estimated with respect to total ${ }^{137} \mathrm{Cs}$ deposited in the valley.
\end{abstract}

\section{HISTORY OF INVESTIGATIONS}

Functioning of the Krasnoyarsk Mining and Chemical Combine (MCC) is a main source of the radioactive contamination of the Enisey-river valley. Two production reactors equipped with only primary cooling system were put into operation in 1958 and 1964, respectively. In 1992 these two straight-through cooled reactors were decommissioned. The third reactor has a closed primary circuit and a secondary cooling system. It is still under operation [1].

Data on the radioactive contamination of the environment caused by operation of the Krasnoyarsk $\mathrm{MCC}$, only recently become available in literature. First investigations of the radionuclide contamination in the Enisey-river were carried out in the early 1970 by the State Committee of Hydrometeorology of the USSR $[1,16]$. Data of this period revealed a considerable contamination of the bottom sediments and the river biota around the MCC. More intensive investigations of the radionuclide contamination in this region were begun in $1990[2,3,9,10,11,14]$. The data were obtained in radioecological expeditions, which were carried out by institutions of the Hydrometeorological Service of Russia (SPA "Typhoon", Obninsk; Institute of Applied Geophysics, Moscow), and by the Siberian Branch of the Russian Academy of Sciences. The airborne-gamma-spectrum data were obtained in framework of the State Radiation Monitoring Program (a leading institution is Institute of Global Climate and Ecology) [4]. Interesting data were received in framework of several intemational projects, performed by the Kurchatov Institute and the Vernadski Institute $[5,11,13,15,16]$. Some results were summarized in the reports of the ISTC. project "Radiation Legacy" (RADLEG). 


\section{GLOBAL FALLOUT IN THE CATCHMENT OF THE ENISEY RIVER}

Global fallout of radionuclides took place in Northern hemisphere mainly during period 1954-1970 with its maximums in 1959, 1963 and 1964. Spatial distribution of radionuclide is mostly determined by interaction between air masses and relief.

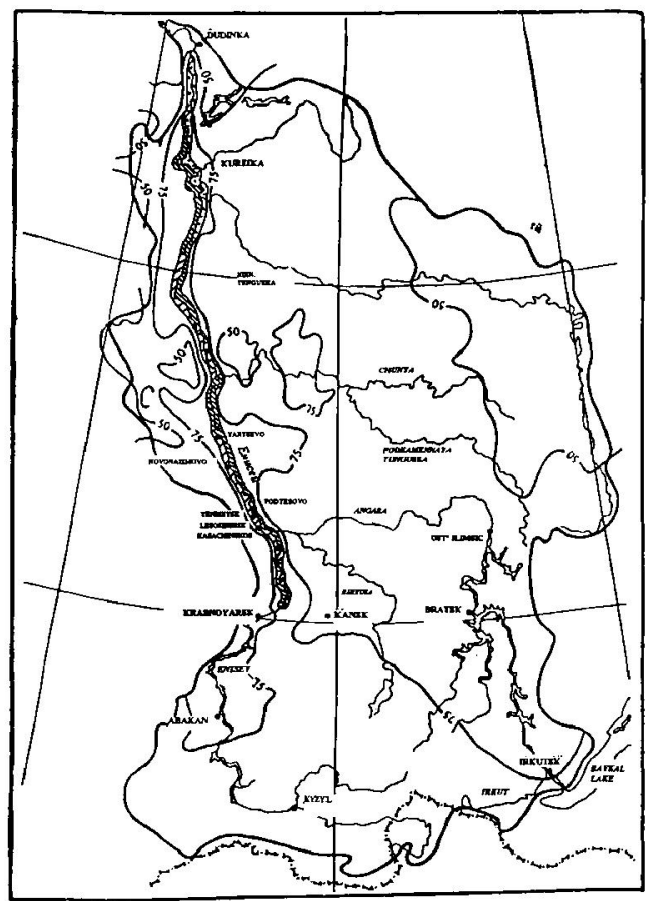

Figure 1: ${ }^{137} \mathrm{Cs}$ contamination of the Enisey catchment in 1999. Area contamination of the catchment is shown in surface contamination density isoclines, in $\mathrm{mCi} / \mathrm{km}^{2}\left(100 \mathrm{mCi} / \mathrm{km}^{2}=3.7 \mathrm{kBq} / \mathrm{m}^{2}\right)$. Contamination along the Enisey River is shown as a linear diagram. 
Airborne gamma-spectrum survey was carried out over the Enisey catchment in the following periods: a) in 1962, i.e. during the initial period of the discharge from straight-through reactors of the MCC into the Enisey river, b) in 1970 after the termination of nuclear tests in the atmosphere, c) in 1993, i.e. immediately after the decommissioning of the straight-through reactors at the MCC.

Survey, carried out by the Institute of Applied Geophysics in 1962, revealed a presence of ${ }^{95} \mathrm{Zr}+{ }^{95} \mathrm{Nb}$, ${ }^{103} \mathrm{Ru}+{ }^{103} \mathrm{Rh},{ }^{140} \mathrm{Ba}+{ }^{100} \mathrm{La}$ in the tropospheric fallout after one of the most intensive periods of nuclear tests in the atmosphere [8]. Contamination with ${ }^{137} \mathrm{Cs}$ during that period played a subordinate role in comparison to ${ }^{95} \mathrm{Zr}+{ }^{95} \mathrm{Nb}$. Average level of ${ }^{137} \mathrm{Cs}$ contamination density was about $2.5 \mathrm{kBq} / \mathrm{m}^{2}$. The survey did not confirm any increase of the in Enisey valley contamination of with this radionuclide. Methodological aspects and features of the equipment of this survey are described in $[6,7,8]$.

Characteristics of the contamination in this area are presented in [9]. The contamination gradually decreases from sout 1 to north from 4.6 to $1.8 \mathrm{kBq} / \mathrm{m}^{2}$ (Fig.1). Relatively increased values of the global contamination of $4.6-5.6 \mathrm{kBq} / \mathrm{m}^{2}$ are found on the right river bank; in several regions, e.g. in the Baikal Lake area, contamination reaches $7.5 \mathrm{kBq} / \mathrm{m}^{2}$. This fact is explained by the relief elevation of the Middle Siberian plateau relative to the West Siberian depression, and by complexity of the highland relief in the upper Enisey flow. The levels of contamination on the left bank are, on the average, equal to 3.7-4.6 $\mathrm{kBq} / \mathrm{m}^{2}$, decreasing in some places down to $2.5 \mathrm{kBq} / \mathrm{m}^{2}$.

To estimate the present levels of contamination mainly of the global origin, we used seven samples taken layer by layer in 1997 along the transverse profile across the Enisey valley at a distance of $500 \mathrm{~km}$ from the point of the radioactive waste discharge. The average level of the global ${ }^{137} \mathrm{Cs}$ in the surveyed area, as of the time of the sample measurement (1999), is estimated as $2-3 \mathrm{kBq} / \mathrm{m}^{2}$. Fig. 2 shows a ${ }^{137} \mathrm{Cs}$ distribution in fine podzol sandy soil on the first terrace above the floodland of the Enisey right bank under the birch and the Siberian pine forest with horsetail-moss-bilberry cover [9]. Vertical distribution of ${ }^{137} \mathrm{Cs}$ in the soil demonstrates a predominance of this radionuclide in the upper $5-10 \mathrm{~cm}$ of soil.

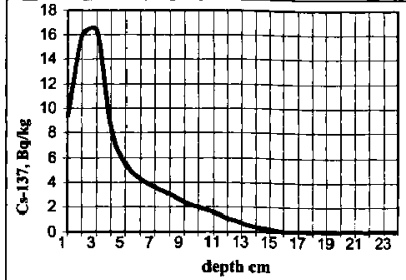

Figure 2: Distribution of ${ }^{137} \mathrm{Cs}$ (mainly global origin) in the Enisey valley (area without of soil accumulation), 1999, total inventory $2.78 \mathrm{kBq} / \mathrm{m}^{2}$.
Moreover, the sampling shows changes of levels of the global contamination with ${ }^{137} \mathrm{Cs}$ under the influence of landscape factors. In the accumulative landscapes the content of this radionuclide increases. For instance, one finds the activity of $3.9 \mathrm{kBq} / \mathrm{m}^{2}$ in the slope of the terrace floodplain in alluvial marshland humus-gley soil; the activity of $6.1 \mathrm{kBq} / \mathrm{m}^{2}$ in the sphagnum bushy swamp of the first terrace above the floodplain in the upper marshland peat soil; at the same time, one finds $2.1 \mathrm{kBq} / \mathrm{m}^{2}$ in the transit part of the periodically flooded central floodplain in alluvial meadow light loam soil, and $2.2 \mathrm{kBq} / \mathrm{m}^{2}$ at the flat top of the terrace above the floodplain without any traces of wash-off or material accumulation in the fine podzol sandy soil.

It is absolutely clear that global contamination is characterized by spatial redistribution in the Enisey valley, which can influence the formation of global anomalies in accumulative landscapes, more than twice exceeding the average levels of the global contamination.

\section{CONTAMINATION OF THE BOTTOM MATERIALS AND OF THE FLOOD-PLAIN SOIL}

It is possible to isolate five periods of the radionuclide contamination of the Enisey valley. First is connected with nuclear bomb testing since 1954. Second period began in 1958 after construction of Krasnoyarsk MCC. The third period started in 1969, when Dam of Krasnoyarsk Hydropower Station was constructed. Hydrological regime of the Enisey River changed seriously after that, and zone of radionuclide contamination essentially squeezed. In the fourth period, Enisey valley was influenced by the low-level Chernobyl deposition of 1986. The fifth period began in 1992 after the decommissioning of two straight-through reactors. 
Radionuclide contamination of the Enisey basin was started together with first the first input from the atmosphere. At the same time, the area of cultivated lands increased from $10 \%$ up to $60 \%$ in Kanskaya and Minusinskaya depressions, which are located in the upper reach of the Enisey basin. As the result, the coefficient of water runoff increased as well as intensity of the soil erosion. The calculated erosion rates exceeded $20 \mathrm{t} / \mathrm{ha}$ per year. Because of the fact that ${ }^{137} \mathrm{Cs}$ is strongly absorbed by clay particles, it is possible to suggest, that a part of global fallout (mostly ${ }^{137} \mathrm{Cs}$ ) was transported by a surface flow with soil particles to the river channels and redeposited along the riverflow. The other possible way of global fallout to the river valley can be associated with snow meiting on frozen soil.

Since 1958, river channel and low floodplain were mostly contaminated, because the radionuclides from Krasnoyarsk MCC entered directly to the river water and then they were spread out with bottomand low floodplain- sediments. Middle floodplain was contaminated mostly during spring floods, and, so, the level of its contamination was lower. High floodplain was contaminated only during high spring floods, which takes place once or twice in a decade. So, the largest part of suspended material and sediment-associated particles can be transported over a long distance and re-deposited far away from its source. That is why the contamination level is very high even at $500-800 \mathrm{~km}$ downstream from Krasnoyarsk-26 (Table 3).

After the Dam construction in 1969 , sediment discharge decreased dramatically downstream from Krasnoyarsk. At the same time, the level of flooding became very low because of the water leve] regulation by Dam. So, the only low floodplain is inundated after 1969. As a result, the total inventory of sediment-associated radionuclides was very high only within limits of low floodplain.

The direct discharge into the water of the Enisey-river for a long time resulted in the contamination of the bottom materials and of the soil of the flood-plain of the Enisey-river.

The long-lived radionuclide composition of the bottom materials for 1992 is shown in the Table 1 from [2], and the radionuclide composition of the soil contamination of the flood-plain of the Enisey-river for the same period is shown in the Table 2 from [2]. At present, after the decay of the short-lived radionuclides $\left({ }^{54} \mathrm{Mn}\right.$ and ${ }^{65} \mathrm{Zn}$ ), the radionuclide composition of the bottom and flood-plain soils have changed.

Table 1: Radionuclide concentration in the bottom accumilative material in the more contaminated parts of Enisey river-bed, $\mathrm{Bq} / \mathrm{kg}$ (dry weight), 1992 [2]

\begin{tabular}{|l|l|l|l|l|l|l|l|}
\hline Distance from the effluence, $\mathbf{k m}$ & ${ }^{51} \mathrm{Cr}$ & ${ }^{54} \mathrm{Mn}$ & ${ }^{60} \mathrm{Co}$ & ${ }^{65} \mathrm{Zn}$ & ${ }^{157} \mathrm{Cs}$ & ${ }^{132} \mathrm{Eu}$ & ${ }^{154} \mathrm{Eu}$ \\
\hline Atarnanovo, 6 & 2442 & 148 & 1813 & 444 & 1443 & 814 & 185 \\
\hline Bolshoi Balchug, 16 & 110 & 148 & 925 & 444 & 163 & 480 & 100 \\
\hline Kononovo, 25 & 126 & 9 & 37 & 11 & 355 & 41 & 11 \\
\hline Predivinsk, 100 & 322 & 27 & 407 & 74 & 218 & 211 & 96 \\
\hline Kazachinskoe, 180 & 111 & 18 & 241 & 48 & 255 & 181 & 33 \\
\hline Strelka, 250 & 444 & 78 & 237 & 74 & 300 & 126 & 28 \\
\hline
\end{tabular}

Table 2:Long-lived radionuclides in the soils of Enisey flood-plain, $\mathrm{kBq} / \mathrm{m}^{2}, 1992$ [2]

\begin{tabular}{|l|l|l|l|l|}
\hline Site of soil sampling & ${ }^{60} \mathrm{Co}$ & ${ }^{13} \mathrm{Cs}$ & ${ }^{152} \mathrm{Eu}$ & \\
\hline 1sland Atamanovski & $200-311$ & $256-350$ & $460-2630$ & $167-1155$ \\
\hline Island Berezovski & $33-118$ & $23-200$ & $59-310$ & $13-100$ \\
\hline Bolshoi Balchug & $\mathbf{3 0 - 7 0}$ & $20-70$ & $30-110$ & $10-30$ \\
\hline Tarygin & $30-70$ & $121-204$ & $0-130$ & $0-25$ \\
\hline Predivinsk & $\mathbf{3 - 9}$ & $7-13$ & $5-11$ & $1-2$ \\
\hline Island Predivinski & $\mathbf{9 - 6 7}$ & $13-100$ & $11-66$ & $1-26$ \\
\hline Momotova & $\mathbf{0 - 5 0}$ & $38-74$ & $0-27$ & $0-6$ \\
\hline
\end{tabular}

Many years of discharge of long-lived radionuclides, including ${ }^{137} \mathrm{Cs}$, into the Enisey river caused contamination of the floodplain. The 1993 survey [4] was carried out over the valley area, downstream Krasnoyarsk-26, $15 \mathrm{~km}$ wide and $500 \mathrm{~km}$ long. Moreover, two routes were performed along the left and right banks of the Enisey river from Krasnoyarsk-26 to Dudinka (i.e. to the mouth of the river in the 
Arctic Ocean), the length of each route was $1760 \mathrm{~km}$. The specific features of the methodology and technical equipment of the survey, using an airborne garnma spectrometry system "Makfar-2" (Canada), are described in [4].

In addition to ${ }^{137} \mathrm{Cs}$, the survey data were examined for other radionuclides. Like at the beginning of $1990 \mathrm{~s}$, the ratio ${ }^{60} \mathrm{Co} /{ }^{137} \mathrm{Cs}$ is estimated for the whole Enisey valley to be equal to $0.7 \pm 0.32$. It was found out, that the ratio slightly varies along the valley. Ratios ${ }^{152} \mathrm{Eu} /{ }^{137} \mathrm{Cs}$ and ${ }^{154} \mathrm{Eu} /{ }^{137} \mathrm{Cs}$ significantly vary with a distance from the source, essentially remaining constant at a distance exceeding $20 \mathrm{~km}$ from the point of discharge. $0-5 \mathrm{~km}$ from the point of discharge, Europium radionuclides typically dominate over those of Caesium in a rather wide range: ${ }^{152} \mathrm{Eu} /{ }^{137} \mathrm{Cs}=1.8-7.5 ;{ }^{154} \mathrm{Eu} /{ }^{137} \mathrm{Cs}=1-3.5-20 \mathrm{~km}$ from the source ${ }^{152} \mathrm{Eu} /{ }^{137} \mathrm{Cs}=1.8 \pm 0.53 ;{ }^{154} \mathrm{Eu} /{ }^{137} \mathrm{Cs}=0.5 \pm 0.06$. At $>20 \mathrm{~km}{ }^{152} \mathrm{Eu} /{ }^{137} \mathrm{Cs}=0.6 \pm 0.17 ;{ }^{154} \mathrm{Eu} /{ }^{137} \mathrm{Cs}=0.12 \pm 0.07$. Such changes of the ratio of Europium isotopes to Caesium possibly may indicate that Europium is mostly contained in hot particles, Caesium migrates more easily in suspensions and in dissolved state. Note, that first $20 \mathrm{~km}$ of the river channel lower the place of discharge is regulated by the dam of the Krasnoyarsk power station, so the river processes are very weak here, and redistribution of the long-lived radionuclides cannot be considerable in the future.

The results of the airborne-gamma-spectrum survey along the Enisey valley are summarised in the Table 3. The number of spectra is about 800000 [4]. The mean levels of ${ }^{137} \mathrm{Cs}$ decreased very slowly. The high values can be registered at a long distance from the source, e.g. $144 \mathrm{kBq} / \mathrm{m}^{2}$ on the left river-side at the $500 \mathrm{~km}$ from the source. The geosystems with the high levels have (as a rule) the small area, i.c. not larger several $\mathrm{m}^{2}$. These geosystems become good natural collectors of the radioactive contamination, and the determination of their geographical positions can be useful for organisation of the countermeasures.

Later 1992, the level of contamination of fresh deposition within the low floodplain area became considerably low and the layers with high radionuclide concentration were buried [11]. This did not take place in middle and high floodplains, where contaminated sediment are still close to surface. So, presently, radionuclide migrates into a soil down to a depth of $>8-12 \mathrm{~cm}$ on the low floodplain, however, on middle and high floodplains maximum of radionuclide contamination is on the surface (like in Fig.2).

Table 3: Results of airborne-gamma-spectrum survey of the Enisey valley, 1993 [4]

\begin{tabular}{|c|c|c|c|c|}
\hline \multirow{2}{*}{$\begin{array}{l}\text { Distance from the soutce of discharge, } \\
\qquad \mathbf{k m}\end{array}$} & \multicolumn{2}{|c|}{${ }^{17} \mathrm{Cs}, \mathrm{kB} q / \mathrm{m}^{2}$ mean } & \multicolumn{2}{|c|}{${ }^{137} \mathrm{Cs}, \mathrm{kBq} / \mathrm{m}^{2} \max$} \\
\hline & \begin{tabular}{|l|} 
Left bank \\
\end{tabular} & Right bank & \begin{tabular}{|l} 
Left bank \\
\end{tabular} & Right bark \\
\hline $0-160$ & 6.29 & 35.9 & $\mathbf{1 8 . 1}$ & 122 \\
\hline $160-320$ & 9.62 & 5.55 & 74 & 121 \\
\hline $320-480$ & 8.51 & 4.07 & 66.6 & 45.1 \\
\hline $4 \overline{80}-6 \overline{40}$ & 8.14 & 5.55 & $\mathbf{1 4 4}$ & 107 \\
\hline $640-800$ & 7.03 & 4,44 & 100 & 28.1 \\
\hline $800-960$ & $8.5 \mathrm{I}$ & 3.33 & 36 & 16.3 \\
\hline $960-1120$ & 7.77 & 4.44 & 45.5 & $23 . \overline{3}$ \\
\hline $1120-1280$ & $\overline{7.03}$ & 4.07 & 33.3 & 24.1 \\
\hline $1280-1440$ & 6.66 & 2.96 & 27.8 & 13 \\
\hline $1440-1600$ & 5.55 & 2.96 & 18.5 & 11.1 \\
\hline $1600-1760$ & 5.92 & 2.59 & 17 & 15.2 \\
\hline
\end{tabular}

The last investigation of the Khlopin Radium Institute (St-Petersburg, Russia) has brought new data on the accumulation of ${ }^{137} \mathrm{Cs}$ and ${ }^{239.240} \mathrm{Pu}$ in the bottom sediments of the estuary of Enisey-river. The increase of ${ }^{137} \mathrm{Cs}$ and ${ }^{239,240} \mathrm{Pu}$ concentration in the bottorn samples is found in the zone of mixing of the sea- and river-waters. The medium rate of ${ }^{137} \mathrm{Cs}$ and ${ }^{239,240} \mathrm{Pu}$ accumulation was estimated [17]: for the southern part of the estuary - 44-163 Bq/m $\mathrm{m}^{2}$ per year for ${ }^{137} \mathrm{Cs}$ and $0.4-4.9 \mathrm{~Bq} / \mathrm{m}^{2}$ per year for ${ }^{239.246} \mathrm{Pu}$, and for the central zone of estuary $-720 \mathrm{~Bq} / \mathrm{m}^{2}$ per year for ${ }^{137} \mathrm{Cs}$ and $8.4 \mathrm{~Bq} / \mathrm{m}^{2}$ per year for ${ }^{239,240} \mathrm{Pu}$. These data show that the increase of accumulation of the weakly soluble radionuclides on the geochemical barrier of estuary is estimated as multiplied by factor 16-20. In the northern part of the estuary (opening to 
the Kara sea), a rate of accumulation decreases down to $3.3-21.4 \mathrm{~Bq} / \mathrm{m}^{2}$ per year for ${ }^{137} \mathrm{Cs}$ and to $0.15-1.4$ $\mathrm{Bq} / \mathrm{m}^{2}$ per year for ${ }^{239.240} \mathrm{P} u$. These data demonstrate the considerable decrease of the radioecological risk.

Basing on the Caesium contamination mapping of the Enisey-river catchment, carried out together with modelling of the erosion and runoff processes, we could calculate total amount of Caesium (for 2001), deposited in the Enisey-river catchment and in the Enisey-river valley during the last 50 years (Table 4).

Table 4: ${ }^{137} \mathrm{Cs}$ in the Enisey catchment and valley, $\mathrm{PBq}$

\begin{tabular}{|c|c|c|c|c|}
\hline Amounh PBq & Global fallout & Chemobyl deposition & Krasnoyarsk-26 discharge & Total \\
\hline Catchment & 5,6 & 0,236 & 0,126 & 5,962 \\
\hline Valley & 0,095 & 0,0047 & 0,126 & 0,226 \\
\hline
\end{tabular}

So, the global fallout with the Chernobyl supplementary deposition gives $98 \%$ in the total Caesium contamination of the Enisey catchment and not less $44 \%$ in the contamination of the Enisey valley.

\section{References}

[1] Vakulovski S.M., Kryshev I.M., Nikitin A.I. Evaluation of the influence of the Krasnoyarsk MiningChemical Enterprise on the radioecology of the Enisey-river.- News of the higher educational institutions. Nuclear energy. - 1994, N2-3, pp.124-129. (In Russian)

[2] Nosov A.V., Ashanin M.V., Ivanov A.B., Martynova A.M. Radioactive contamination of the Eniseyriver caused by the effluences of the Krasnoyarsk Mining-Chemical Enterprise. - Atomic energy, 1993, v.74, i.2, pp.144-150. (In Russian)

[3] Nosov A.V., Martynova A.M. Estimation of the radiation situation on the Enisey river after the decommissioning of the straight-through cooled reactors of the Krasnoyarsk Mining-Chemical Enterprise.- Atomic energy, 1996, v.81, 1.3, pp.226-232. (In Russian)

[4] Kontarovich R.S., Fedotkin A.F., Kertzman V.M. Airbom-gamma-spectrum survey of the valey of the Enisey-river. State scientifical-technical enterprise "Aerogeophysics" under the Ministry of Geology. Report on the theme "Atlas" of the Hydrometeorological Service of Russia. 1993. (In Russian)

[5] Radioactive Contamination of Rivers and Transport Through Rivers, Deltas and Estuaries to the Sea. NATO/CCMS Pilot Study: Cross-border environmental problems emanationg from defence-related installations and activities. Phase II: 1995-1998, Final Report N 225, pp.25-29.

[6] Boltneva L.I., Izrael Yu.A., Ionov V.A., Nazarov I.M. ${ }^{137} \mathrm{Cs}$ and ${ }^{90} \mathrm{Sr}$ global contamination and external doses on the USSR territory. - Atomic Energy, v.42, issue 5, 1977, p.355-360 (in Russian).

[7] Kogan R.M., Nazarov I.M., Fridman Sh.D. Airborn-gamma-spectrometry of the environment. Issue 3. - Moscow: Energoatomizdat, 1991. - 233 p. (in Russian).

[8] Izrael Yu.A. Radioactive fallout after the nuclear explosions and accidents. - St-Petersburg: ProgressPogoda, 1996, 355 p. (in Russian).

[9] Kvasnikova E.V., Kertzman V.M., Nazarov I.M., Stukin E.D., Telesnina V.M., Fridman Sh.D. Study of the valley and catchment of the river enisey using airborne gamma spectrometry method. Proceedings of the International Conference "Radioactivity after the nuclear explosions and accidents", Moscow, 24-26 of April, 2000, Vol.1, pp.549-554. (In Russian)

[10] Sukhonkov F.V., Melgunov M.S., Kovalev S.I. Some features of distribution of technogenic radionuclides in alluvial soils and in bottom sediments of the Enisey-river in the near zone of the Krasnoyarsk Mining and Chemical Combine. Proceedings of the Intemational Conference "Radioactivity after the nuclear explosions and accidents", Moscow, 24-26 of April, 2000, Vol.1, pp.537-542. (In Russian)

[1 1] Linnik V.G., Govorun A.P., Potapov V.N., Sadyrev D.N., Shishlov A.E., Degermendzhi A.G. Landscape features of radionuclide distribution in the floodplain of the Enisey-river in the proximate zone of the influence of the Mining and Chemical Combine. Proceedings of the International 
Conference "Radioactivity after the nuclear explosions and accidents", Moscow, 24-26 of April, 2000, Vol. I, pp.543-548. (In Russian)

[12] Nosov A.V. Investigation of migration processes of radioactive elements in the floodplain of the Enisey-river. Meteorology and Hydrology, 1997, N 12, pp.84-91. (In Russian)

[13] Sukhorukov F.V., Melgunov M.S., Kovalev S.I. Main peculiarities of the distribution of artificial radionuclides in the alluvial soils and bottom sediments of the Enisey-river. Siberian Ecological Journal, 2000, vol.7, \#1, pp.39-50. (In Russian)

[14] Bolsunovsky A.Ya., Goryachenkova T.A., Cherkesyan B.O., Myasoedov B.F., Hot particles in the Krasnoyarsk region. Radiochemistry. 1998, V.40, N 3, pp.271-274. (In Russian)

[15] Kuznetzov Yu.V., Ltgin V.K., Shishlov A.E., Stepanov A.V., Savitski Yu.V., Strukov V.N., Study of the 239,240Pu and 137Cs behaviour in the system of Enisey-river - Kara sea. Radiochemistry, 1999, vol.41, N 2, pp.181-186. (In Russian)

[16] Vakulovski S.M., Kryshev I.I., Nikitin A.I., Savitski Yu.V., Malyshev S.V., Tertyshnik E.G. Radioactive contamination of the Enisey-river. J.Environ.Radioactivity. Vol 29, N 3, pp.225-236, [995.

[17] Legin V.K., Kuznetzov Yu.V., Strukov V.N. Investigation of distribution and migration of radionuclides in the estuary of the Enisey-river. In: Proceedings of abstracts of presentations on the International scientific Conference "Radioecological problems of the European seas of Russia (sources, concentrations, environmental impact)', June, 24-26, 2001, Rostov-on-Don, pp.43-44 (In Russian). 